\title{
DISTINCTIVELY CHRISTIAN ENGINEERING: AN EVALUATION OF OUR CIVIL CURRICULUM
}

\section{Author: \\ Dr J K Sikkema ${ }^{1}$ \\ J R. Van der Werff ${ }^{1}$ \\ Affiliation: \\ ${ }^{1}$ Assistant Professor of Engineering, Dordt College \\ Correspondence to: Dr J K Sikkema \\ Email: \\ Justin.VanderWerff@ dordt.edu}

\section{Postal address:}

498 Fourth Ave. NE, Sioux

Centre, lowa, 51250, USA

\section{Correspondence to:}

J R. Van der Werff

Email:

Joel.Sikkema@dordt.edu

\section{Postal address:}

498 Fourth Ave. NE, Sioux Centre, lowa, 51250, USA

Dates:

8 Dec 2015

How to cite this article: Sikkema, J.K. \& Vander Werff, J.R., 2015. "Distinctively Christian Engineering: An Evaluation of our Civil Curriculum". KOERS Bulletin for Christian Scholarship, 80(3). Available at: http:// dx.doi.org/10.19108/ koers.80.3.2239

\section{Copyright:}

(c) 2015. The Author(s).

Published under the

Creative Commons

Atribution License.
As professors in an engineering program developed with the intention of being Christ-centred and holistic, one of our responsibilities is to equip our students to serve the Lord obediently in all that they do-especially in engineering. To serve as the foundation of this preparation, we used a previous publication which set out five distinctively Christian guiding principles for engineering. Our intent is that these principles will be used to direct the development and modification of our engineering curriculum. Directing these efforts requires a grounding point. Therefore, this paper evaluates the extent to which these principles are already emphasized in the program's civil engineering curriculum. Comparing this evaluation to benchmarks for each of the five principles revealed that the curriculum fell short. This result was expected because the curriculum does not contain a formal process to introduce, emphasize, and apply these principles. The evaluation determined that the first principle, which recognizes that the world and everything in it was created for God's glory, fell the farthest from its benchmark. Since this principle is foundational to all the other principles, efforts to increase the emphasis of this principle should be given the highest priority.

$$
\text { } \ldots \ldots \ldots \ldots \ldots \ldots \ldots \ldots \ldots \ldots \ldots \ldots \ldots \ldots \ldots \ldots \ldots
$$

As professore in ' $n$ ingenieursprogram wat ontwikkel is met die doel on Christo-sentries en holisties te wees, was een van ons verantwoordelikhede om ons studente toe te rus om die Here met gehoorsaamheid te dien in alles wat hulle doen - veral in ingenieurswese. As ' $\mathrm{n}$ fondasie vir hierdie voorbereiding, het ons ' $n$ vorige publikasie gebruik waarin vyf duidelike Christelike rigtinggewende beginsels vir ingeneiurswese uiteengesit word. Ons bedoeling is dat hierdie beginsels gebruik sal word om die ontwikkeling en wysiging van ons ingenieurskurrikulum te onderlê. Om rigting te gee aan hierdie poging moet ons die proses anker, en daarom sal hierdie artikel die omvang evalueer van die bereiking van hierdie beginsels in die program se siviele ingenieurswesekrrikulum. As mens hierdie evaluering vergelyk met doelwitte wat gestel is vir elkeen van die vyf beginsels, it is duidelik dat die kurrikulum tekortskiet. Hierdie uitkoms was te verwagte omdat die kurrikulum nie 'n formele proses bevat om hierdie beginsels bekend te stel, te onderstreep en toe te pas nie. Die evaluering het bepaal dat die eerste beginsel, wat is dat alles geskep is tot die eer van God, en hierdie beginsel het die meeste tekort geskiet. Aangesien hierdie beginsel die fondasie is vir al die ander beginsels, moet pogings aangewend word om die belang van en onderstreping van hierdie beginsel die hoogste prioriteit te gee. 


\section{INTRODUCTION AND BACKGROUND}

Soli Deo gloria, glory to God alone-Dordt College strives to use these words as the guiding principle for all activities. We, the authors, are new faculty members in Dordt's engineering programme and we are daunted! Our courses require a high level of technical expertise and we have a duty to demonstrate that our Reformed faith is foundational to the way we practise engineering. With graduate degrees in civil engineering, we are equipped to develop the technical expertise needed for an engineering programme; however, we recognize that we need to deliberately and carefully consider what it means to do engineering for God's glory alone. We began to cultivate this understanding by identifying a set of distinctively Christian guiding principles for engineering, which recognize the holistic nature of serving obediently as engineers in our imperfect world (Vander Werff, Sikkema \& Brue 2013). This paper, a follow-up to previous work, critically evaluates the existing civil engineering curriculum at Dordt College. Specifically, the paper seeks to determine whether what has been professed to be of critical importance for a Christian engineering student is demonstrated in the institution's civil engineering curriculum. To achieve this goal, our article (1) evaluates the extent of each principle's emphasis in the civil engineering program, (2) reflects on which principles are not adequately emphasized, and (3) identifies program changes that must be made to remedy deficient areas.

\subsection{Engineering in the creation-fall- redemption narrative}

Our biblical foundation informs the way we view the world and thereby guides how we work as engineers [for extensive discussion, see Vander Werff et al. (2013)]. This section offers a brief insight into the blocks that form such a foundation and the basis it provides for our work as engineers. But before digging into these topics, we want to make one thing clear: in our work we are not advocating the one and only biblical approach to engineering education. Rather, we are sinful finite humans attempting to interpret God's Word in order to develop an obedient curriculum.

Our foundation is organized into what is termed the CreationFall-Redemption paradigm. At the outset of creation, God gave humanity the task to be his representatives in creation. With words such as subdue, have dominion, work, and keep (Genesis 1:28 and 2:15 ), humans were given the task to tend to God's world in a manner that both develops its potential and ensures that human activities do not impair its ability to flourish in the future (Timmer 2009). The fall radically altered humanity's relationship with God and his creation. Paul teaches in Romans 3:23: 'All have sinned and fall short of the glory of God'. Furthermore, the reach of the fall spreads far beyond humanity. Romans 8 states that as a result of the fall 'the creation was subjected to futility, not willingly,' and that 'the whole creation has been groaning together' under the effects of sin. All portions of creation continue to suffer the effects of the fall; however, Christ is reconciling all things (humankind and the physical creation) through his blood (Colossians 1:20).
In engineering, this reconciliatory work is manifested as a duty to use science and technology to unfold the potential of creation in a manner that exhibits care for the entirety of creation: humans, other creatures, and the natural environment (ed. Monsma 1986). This challenging duty is not limited to the stovepipes of traditional engineering disciplines; rather, it requires a recognition of and extension to all aspects of reality. In recognition of this biblical mandate, a Christian engineering curriculum should seek to equip students to obediently and normatively glorify God and love neighbour in an untold number of service areas.

\subsection{Guiding principles for engineering}

Recognizing the all-encompassing nature of God's creative work, humanity's fall into sin, and Christ's reconciliatory work, we developed guiding principles to help us structure an engineering curriculum that equips and makes disciples of students to serve obediently and effectively in the tasks God places before them. These principles are summarized in Figure 1 , and a detailed explanation of each principle can be found in Vander Werff et al. (2013).

Since the time of writing the initial publication on this topic, we have gathered feedback from students and faculty (both within and outside the institution). On the basis of this feedback, the principles were further developed and rephrased to more effectively capture the original intent. The fifth principle, 'we live in the already and not yet of Christ's kingdom', reads as markedly different from the initial phrasing. This revision emphasizes the condition of the present state of engineering work. Christ has already accomplished His climactic victory over sin on the cross and in His resurrection. However, He has not yet fully restored His kingdom; this final state will only be entirely realized upon His second coming and judgment. Specific Scriptural revelation has not been given to inform how service to the Lord, which works to ease the effects of sin, relates to Christ's reconciliatory work, which will eradicate sin and translate into the completely renewed heavens and earth. Christ has called humanity to unfold the potential of His creation, and nothing in Scripture indicates that the fall has abdicated this responsibility. Christ may choose to use creaturely works as a vehicle to accomplish the Spirit's work of reconciling a sinful heart to Him, and He may choose to use humanity's creaturely hands to unfold or reconcile a small portion of the non-human creation to Him. However, these thoughts merely speculate on humanity's participation in Christ's reconciliatory work to provide encouragement to avoid falling into a dualistic 'spiritual' and 'physical' mind-set, rather than to promote ourselves as the saviours of the world. The Bible explicitly and repeatedly names Christ as the reconciler (Romans 5:10-11, 2 Corinthians 5:18-19, Ephesians 2:16, Colossians 1:20, for example). In no instance have humans been given this duty. Contrary to some philosophies, Christians do not work to save the world. Rather, the reason Christians work is out of gratefulness for the saving work that Christ has done and to continue the sanctifying work of the Spirit in their lives. 
Figure 1. Summary of distinctively Christian guiding principles for an engineering curriculum

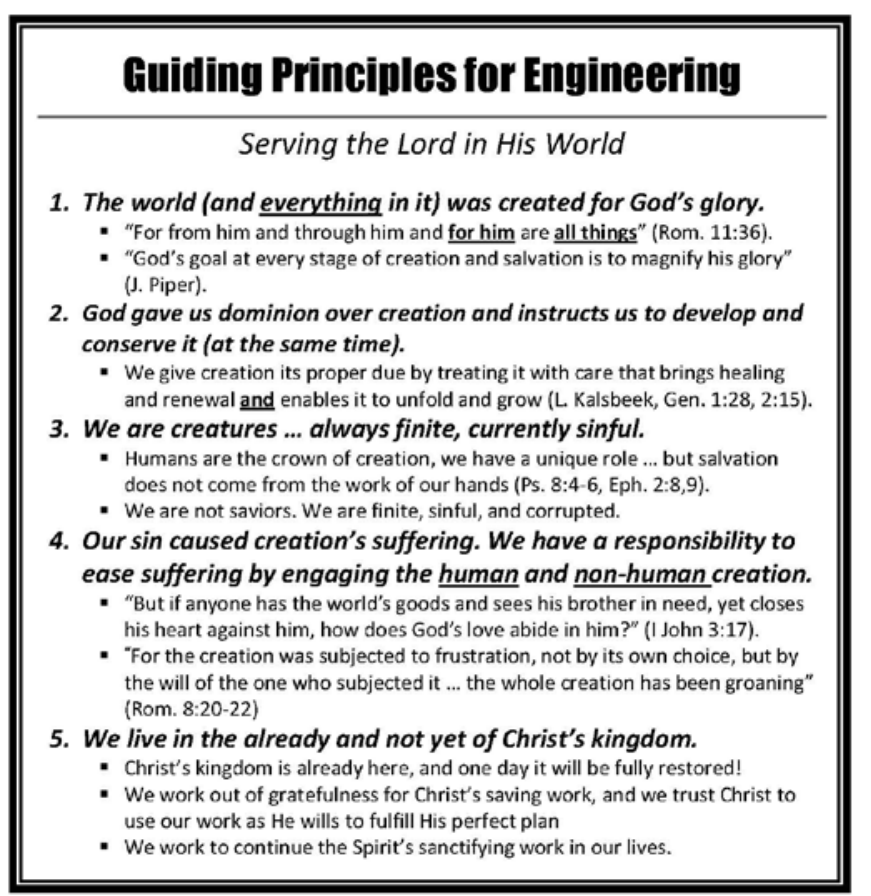

\section{EVALUATIVE METHODS}

The developed guiding principles provide a worthwhile framework that develops student understanding that their life, work, and engineering occurs within Christ's creation-fallredemption story. This framework has helped us, the authors, as we design courses. However, a broader intent is that these principles will direct the development and modification of an engineering curriculum. These larger-scale efforts were aided by the development of a quantitative evaluation tool that characterizes the emphasis placed on each principle within both courses and the civil engineering curriculum as a whole. The subsections below describe the development of a course scorecard, curriculum scorecard, and curriculum benchmarks.
Prior to reading the following descriptions of these components, note that this tool was used cautiously. Like any quantitative evaluation system it is inherently reductionistwhich is the very thing the principles try to avoid. However, if mindful of these limitations, this tool can be used as one way to evaluate the extent to which each principle is emphasized in the institution's engineering courses and curricula.

\subsection{Course scorecard}

To evaluate the civil engineering program, principle emphasis scores were determined for all courses students would take to complete their degree. In cases where multiple options existed to meet a curricular requirement, the selected option was the course most commonly selected by our students. The evaluation considered all courses in the curriculum, including engineering, math-science, and core. For this institution (Dordt College), it is most appropriate to include all the courses, and not just the engineering courses. The curriculum is set up so the tapestry formed by weaving the threads of core courses and engineering courses is crucial to the development of a holistic understanding of engineering for students.

With the courses in a curriculum identified, these courses were then scored for the emphasis placed on each of the five guiding principles. These scores ranged from o to 4 , with o being the least emphasis and 4 being the most emphasis. In an effort to reduce the variable and arbitrary nature of numerically scoring nonnumerical principles, scores were provided by both the authors and all faculty members involved in teaching these courses. Although the number of people involved in scoring each course was small, each person drew on additional resources in order to minimize personal biases. These resources did include student course evaluations and comments in order to minimize differences between faculty and student perceptions.

The average of these multiple scores was used to develop the curriculum scorecard described in the following section. For reference, Table 1 displays an example of the scoring for EGR 212 (Mechanics of Materials), which is a 4-credit course that consists of 3 classroom credits and 1 lab credit.

Table 1. Course Scorecard for EGR 212 (Mechanics of Materials, Dordt College).

\begin{tabular}{|c|c|c|}
\hline Principle & Score (1-4) & Description \\
\hline 1 & 2 & Talked about but not emphasized \\
\hline 2 & 4 & $\begin{array}{l}\text { Heavy emphasis on understanding mechanics principles with an underlying motive of } \\
\text { unlocking the potential in creation }\end{array}$ \\
\hline 3 & 4 & $\begin{array}{l}\text { Especially in the lab, students are introduced to the limitations of our understanding and our } \\
\text { equipment }\end{array}$ \\
\hline 4 & 1 & Minimal discussion \\
\hline 5 & 1 & Minimal discussion \\
\hline
\end{tabular}




\subsection{Curriculum scorecard}

To evaluate principle emphasis scores in light of curriculum benchmarks required the aggregation of course scorecards into an appropriately-weighted curriculum scorecard. Recognizing that a four-credit course influences a student to a greater degree than a two-credit course, scores were averaged based on the number of credits in a course. To complete this averaging calculation, the principle emphasis scores for each course were multiplied by the number of academic credits for the course. These values were then added together for each course in the civil engineering curriculum. Finally, this total was divided by the number of academic credits in the curriculum. Practically speaking, this calculation followed the same steps that can be used to determine a student's grade-point average.

\subsection{Curriculum benchmarks}

To aid in reflection on the gathered data, benchmark emphasis scores were set for each principle. A curriculum emphasis score that meets or exceeds this benchmark would indicate adequate emphasis of a principle in the program. Although these benchmarks were easily proposed, settling on appropriate values represented a challenge. This difficulty arose because the principles do not operate as five parallel threads. A better framework considers principles 2,3 , and 4 as naturally growing from the understanding of principle 1; with these same three principles residing within the 'already and not yet' of principle 5. In this framework, the first principle provides the foundation from which the second, third and fourth principles arise. The fifth principle forms a cloud that encompasses principles 2-4, but then extends far above and beyond them.

In this light, the specific nuts and bolts of obedient engineering that gets discussed throughout an engineering curriculum tend to reside more within principles $2-4$. Thus, in a curriculum with adequate principle representation, one would expect to observe moderate emphasis on principles 2, 3, and 4. A normative approach to principles 2-4 requires the foundation developed by principle 1; therefore, principle 1 must have the highest emphasis in a curriculum. Such a target is not warranted for principle 5 because specific course topics do not directly relate to this principle but rather point towards it. With this logic, target curriculum emphasis scores were set at 3.0, 2.5, and 1.5 for principle 1, principles 2-4, and principle 5, respectively.

Although these ratings appear arbitrary and robotic, their validity comes from a broader set of efforts that guided selection of the target scores. The developed principles follow from a perspective on engineering that is conscious of and obedient to the biblical narrative of Christ (Vander Werff et al. 2013). This Creation-Fall-Redemption (CFR) narrative recognizes humanity's purpose for being created and need for a Saviour, Christ's climactic sacrifice and resurrection, and humanity's present and future hope in Him. Having developed the principles from this basis and recognizing the authors' own finitude, we worked with faculty both within and outside our institution to critically evaluate our efforts. In addition, we test drove these principles with activities that helped us judge whether the principles resonated with our students. These efforts have helped us to develop our work into statements that are an effective tool that we can use to shape the minds of our engineering students. These efforts also gave us confidence that the principles provide a worthwhile characterization of what it means to serve the Lord obediently in an imperfect world. However, this development and these target ratings are certainly not complete, and we welcome feedback from peers that will help us become more effective as we serve our students.

\section{CIVIL CURRICULUM RESULTS}

Table 2 reports benchmarks and principle emphasis scores for the institution's civil engineering curriculum. This narrow focus on the civil engineering program is for brevity and clarity and also in recognition that since we teach courses in the civil curriculum, this concentration is the area where we have the most course input and thus can affect the largest change. Although the civil curriculum scorecard is reported, the small size of the department provided the opportunity to also develop curriculum scorecards for the institution's mechanical, biomedical, and chemical curricula. These scorecards each reported quite similar information (which is not surprising since there is substantial course overlap between these four concentrations).

Table 2. Comparison of Dordt College civil-concentration curriculum benchmarks to principle emphasis scores

\begin{tabular}{|l|l|l|c|}
\hline Principle & Curriculum benchmark (0-4) & $\begin{array}{l}\text { Curriculum principle emphasis } \\
\text { score (0-4) }\end{array}$ & $\begin{array}{c}\text { Difference between score and } \\
\text { benchmark }\end{array}$ \\
\hline 1 & 3 & 1.8 & -1.2 \\
\hline 2 & 2.5 & 2.2 & -0.3 \\
\hline 3 & 2.5 & 1.6 & -0.9 \\
\hline 4 & 2.5 & 1.8 & -0.7 \\
\hline
\end{tabular}




\begin{tabular}{|l|l|l|l|}
\hline 5 & 1.5 & 0.9 & -0.6 \\
\hline Average & 2.4 & 1.7 & \\
\hline
\end{tabular}

\section{DISCUSSION OF EACH PRINCIPLE BASED ON THE CASE STUDY}

The developed curriculum scorecard and benchmarks served as a means to compare goals for the emphasis of the principles to their actual emphasis within the civil engineering curriculum. This comparison provided a basis that was used to evaluate why the recorded scores fell below the target and whether action should be taken to raise the scores. This evaluation, first considered the combined average score of all principles and then evaluated each individual principle. Based on these evaluations, actions were suggested that could be taken to raise the principle scores to the set targets.

Overall, the principle emphasis scores averaged 1.7 and ranged from 0.9-2.2 on a 4-point scale. This average fell substantially below the 2.4 benchmark average. The results indicate that the targets are not being reached; therefore, efforts should be made which result in greater exposure to these principles within the curriculum. This conclusion sounds too machinelike-almost like the boiler that supplies steam to heat the institution's buildings. If the temperature falls too low, the boiler's steam production is ramped up. In this case, the principle emphasis fell too low, so activities that expose our students to these principles should be ramped up. However, these initial ratings and initial actions are simply a starting point; the implementation and evaluation of these principles will be an ongoing continuous improvement process in the years ahead that will evaluate and re-evaluate benchmarks and more importantly determine how accurately the ratings reflect the students' true understanding and appreciation for a holistic, normative understanding of engineering.

To raise the average principle score will require action. However, moving the needle towards our target is not perceived to be overly difficult. To date, no formal process exists to introduce, emphasize, and apply these principles. Rather, the scores obtained reflect objectives already present within the courses. Therefore, any sequence of learning activities dealing with the principles in a meaningful way will elevate the principle emphasis scores.

When considering specific actions to elevate the principle scores, it is important to recognize that they are based on a CFR paradigm. While many students enter the institution with a basic understanding of this model, there are some students who have not viewed the Bible in this context. Dordt College's core curriculum exposes students to the CFR paradigm during the first two semesters of their education. Therefore, it is wise to wait to introduce our students to these principles until their third semester of study. This proposal should not be interpreted as saying that conversations about how faith in Christ impacts engineering should wait until this point. These discussions already occur within the curriculum. Rather, specific articulation of these five principles can wait until students have been equipped with the tools and reached a maturity that allows them to meaningfully analyse, evaluate, and apply the principles to the area in which they plan to serve after they complete their formal education.

\subsection{Principle 1: The world (and everything in it) was created for God's glory.}

Compared to the other principles, this principle's 1.8-point score placed it in the median position. However, on the basis of difference between recorded and benchmark scores, this principle fell furthest from its target. The 1.2-point difference in scores indicated that efforts to increase the emphasis of this principle should be given the highest priority.

Recognition that the world was created for God's glory provides direction for all of an engineer's work. For engineers, this principle offers a reminder of the ultimate purpose of their work. However, the principle also reminds engineers that their work must not impede the efforts of other people or other parts of creation to glorify God. With this overall direction set, the relevance of the four remaining principles becomes much clearer.

Since this principle is foundational to the remaining four, efforts to increase the emphasis placed on this principle must occur early in the curriculum. Unlike some of the principles that follow, this principle rests far above an engineer's day-today duties. This disconnect may make success difficult; in their first few semesters of study, some students have not yet reached a maturity that recognizes the importance of the broader context of engineering. Although this task will be difficult, recommended activities include appropriate readings, in-class discussions, and personal reflections. Furthermore, given the relatively small size of the department, opportunities exist to develop closer ties between cohorts in which our older students help to mentor those who are joining our program.

\subsection{Principle 2: God gave us dominion over creation and instructs us to develop and conserve it (at the same time)}

At 2.2 points, this principle scored higher than any other principle. In addition, this principle had the lowest deviation between recorded and target scores (-0.3). This low deviation is attributed to existing themes within our curriculum and a tendency for our engineering students to gravitate to this principle.

The curriculum emphasizes that one of an engineer's roles is to be faithful to God's call to develop His creation. Instructors introduce this perspective in the first engineering course of our curriculum. As students progress through their education, 
continued efforts deepen their understanding of what it means to do engineering for God's glory. This deepening is concluded with a thorough investigation of the biblically-grounded framework and guiding norms for technology developed within Responsible Technology (ed. Monsma 1986).

Student feedback and personal experience indicate that this principle resonates with Dordt's engineering students. These students are people who already have a passion for designing and building things. When shown that their passion is one example of faithful service to the Lord and that engineering may be where the Lord calls them to serve, they readilyperhaps with too little critical evaluation-accept the principle.

Although evidence exists that this principle is emphasized within the curriculum, faculty discussions revealed that work needs to be done to help the students recognize conservationthe second part of the principle. In an engineer's passion for development, they can lose sight of the effect of this development on the rest of creation. Left unchecked, this development could hamper creation's ability to live out its call to bring glory to God. Engineers need to recognize the setting within which their work occurs. When they take action to develop the creation, they should also seek to enable the non-human creation to flourish and bring glory to God. No doubt, this goal of interdependence with the creation is difficult to achieve. But if engineers find these opportunities, they find new ways for Christ's glory to shine through all of creation, not just themselves.

To address this deficiency, recommended actions include project- or problem-based activities that put engineering in context. Activities should not only ask students to solve an engineering problem, but also require that they consider broader impacts on the natural creation and on the ability for other people to live out their callings. It is expected that these activities will occur throughout the curriculum.

\subsection{Principle 3: We are creatures ... always finite, currently sinful}

This principle's 1.6-point score placed it near the average on the scorecard and put it 0.9 points below our target. Recognizing this substantial difference between recorded and target scores, it is evident that targeted efforts will be needed to elevate this score.

The statement 'We are creatures' has an instrumental role in reinforcing principle 1 and restraining principle 2. The first principle recognizes that ultimately the world exists for God's glory. Humans do not exist for their own gain or selfsatisfaction, they exist to glorify God. Principle 3 helps to reinforce this truth. Although humans were made in God's image and are the crown of His creation, they are finite and sinful. As much as engineers would like to use their ingenuity and the works of their hands to develop engineering solutions that save the world, the place of this work must be recognized. The world's salvation only comes through Christ's reconciling work. Creatures can only hope to be obedient, grateful servants of Christ in his ongoing work. Despite efforts to follow God's norms for development, sin becomes manifest in the artefacts that engineers create. What engineers think are solutions frequently are full of deficiencies and unintended negative impacts on others.

As ways to elevate this score were considered, it was clearly observed that the students recognize the creaturely-ness of humanity. They make mistakes, their professors make mistakes, and the technology they use is never error-free. The students have learned to live with these effects of sin. But, they sometimes fail to recognize how their own sinful natures can become embedded in the things they create. At times, they fail to see that their design decisions are not neutral but reflect the values that they hold-values that either work towards or against God's kingdom. Getting students to recognize these greater permeations of sin will not be an easy task. Proposed actions include developing case studies that demonstrate and reinforce this fact. However, these learning activities must be used carefully and after the students have become mature enough to have the confidence to stand apart from prevailing views in both broader culture and the Christian community.

\subsection{Principle 4: Our sin caused creation's suffering. We have a responsibility to ease suffering by engaging the human and non- human creation}

Falling 0.7 points below its 2.5-point target, this principle also represented an area that requires improvement. As means to raise this score were considered, it became evident that this principle has close ties to principle 2. Specifically, recognizing a call to develop and conserve, it follows that these efforts should be directed to easing suffering within creation caused by $\sin$. Recommended actions include emphasizing this principle alongside the project- or problem-based activities that emphasize principle 2. Students will also need to be equipped to recognize that the effects of sin have permeated all of creation, but it is expected that this truth can be developed within the institution's existing core curriculum and existing learning activities.

\subsection{Principle 5: We live in the already and not yet of Christ's kingdom}

Although this principle received the lowest score (0.9), findings indicate that only a moderate increase (0.6) in the emphasis of this principle would be required to achieve the target ranking. At the outset of this case study, a low target value was set (1.5) for this principle. This principle provides a conclusion for the other principles that puts an engineer's work in context and directs how they serve.

The thoughts contained within this principle require maturity, a maturity that not all students reach within their time at the institution. Recognizing this inherent difficulty, efforts to convey this principle's relevance should wait until the seventh or eighth semester of a curriculum. This principle is also difficult to connect directly with engineering activities. Therefore, reflective essays and class discussions represent the best options to convey this principle's importance. 


\section{CONCLUSIONS}

The first paper on these distinctively Christian guiding principles for engineering concluded by asking, 'Where do we go from here' (Vander Werff et al. 2013). Asking this question is also a fitting way to wrap up this article. To know where to go next, we reflected upon our starting point. We are early in our careers as professors at Dordt College. As we work towards excellence in this part of our calling, we recognize that we need to develop a deeper understanding of what it means to serve as engineers within the grand narrative of Christ's reconciliatory work. Developing the principles was a first step in deepening this knowledge. Equipped with these principles, we need to take steps to utilize these principles in our classes. This effort will be a multistep process and embarking upon it requires a grounding point. The evaluation reported in this paper provides the point of reference and sets the direction needed to move forward and make these principles integral to the curriculum. This paper found evidence that efforts should be made to increase the emphases of all of the principles. In particular, it recognized that the highest priority should be placed on developing the students' understanding that 'the world (and everything in it) was created for God's glory'. As efforts to use and apply these principles continue, there will be opportunities to share findings in future articles. We look forward to demonstrating the unique advantages offered in a small college where we can easily form mentoring relationships outside the classroom and use sequential courses to build both technical and perspectival understanding. We also look forward to sharing how the diverse personalities of faculty members can be unified and directed to connecting these principles with students from varied backgrounds. Overall-and harking back to the first paper in this series-we recognize that ultimately we exist as a part of Christ's narrative, and we look forward to sharing our opportunities to continue to serve in his story. 


\section{REFERENCES}

Monsma, S. V. (ed.), 1986, Responsible Technology: A Christian Perspective, Wm. B. Eerdmans Publishing, Grand Rapids, Michigan, USA.

Timmer, K. J., 2009, 'Putting the 'and' back into Genesis 2:15', in J. VanAntwerp (ed.), Proceedings of the 2009 Christian Engineering Education Conference, Waco, Texas, USA, June 17-19, 2009, 3-9.

Vander Werff, J. R., Sikkema, J. K., \& Brue, E. J., 2013, 'Working Toward a Distinctively Christian Engineering Curriculum' in J. VanAntwerp (ed.), Proceedings of the 2013 Christian Engineering Conference, Atlanta, Georgia, USA, June 26-28, 2013, pp. 56-73. 